\title{
Behavioral factors for IT project success in Pakistan: Moderating effect of leadership styles
}

\author{
Muhammad Asghar Mughal ${ }^{\mathrm{a}}$, Ahmad Yusni Bahaudin ${ }^{a^{*}}$ and Nurul Azita Salleha
}

${ }^{a}$ School of Technology Management \& Logistic, Universiti Utara Malaysia, Sintok, 06010 Sintok, Kedah,Malaysia

\begin{tabular}{l}
\hline C H R O N I C L E \\
\hline Article history: \\
Received: March 12, 2019 \\
Received in revised format: April \\
102019 \\
Accepted: April 12, 2019 \\
Available online: \\
April 12, 2019 \\
\hline Keywords: \\
Project success \\
Pakistan \\
Critical success factors \\
IT projects
\end{tabular}

\section{A B S T R A C T}

\begin{abstract}
Nowadays, there are many uncertainties and risks prevailed in environment especially for information technology (IT) projects in Pakistan context. Behavioural aspects of project management play important role to attain success. Soft dimension of project implementation profile consists of critical success factors like top management support and client acceptance. The proposed study of this paper designs a questionnaire and examines the relationship between behavioural factors and project success. There were 223 respondents from the population of Pakistan software board directory. The results indicate that client acceptance had a positive and significant relationship with project success. Moderation was performed categorical of leadership style; transactional and transformational leadership style.
\end{abstract}

(C) 2019 by the authors; licensee Growing Science, Canada

\section{Introduction}

Uncertainty is not a neglectable aspect of all projects especially IT project in Pakistan (Gällstedt, 2003; Tatikonda \& Rosenthal, 2000); it can confront in several states. It includes uncertainty pertained to time to complete particular operations within a project, uncertainty pertained to accessibility of resources that might helpful in project completion and uncertainty to realize that other projects may influence the certain project (Verma \& Sinha, 2002). Environment is influenced by task uncertainty and informational procedure can provide fundamental benefits for decision-making (Galbraith, 1977).

Many managers require to learn more about the role of increased information which can influence on the success of the information technology (IT) projects. This is conceivable with immediate evolution of modern IT infrastructures capable of allocating task-related information more brilliantly (Bendoly \& Swink, 2007). It is essential to classify that operations of individuals stimulated with complex tasks (project management) can be inspired by task definite (rational) objects and non-task benefits (social). Operations based on non-task social options may not surely donate positively to the individuals' tasks. They may actually sub-standard such outcomes. Subsequently, they may be focused towards negative or positive effects on other parties (O'Reilly \& Chatman, 1986; Puffer, 1987).

* Corresponding author.

E-mail address: aybahaudin@gmail.com (A. Y. Bahaudin)

(C) 2019 by the authors; licensee Growing Science, Canada doi: $10.5267 /$ j.msl.2019.4.006 
Commonly in environments where several parties interconnect to assign limited resources (situations of project management), comparable informational process which give insights towards higher working performance can also work to bias perceptions of organizational behaviour (Bendoly \& Swink, 2007).

The particular field of project management (PM) today is diverse, multifaceted and inconsistent in many respects such as Rapid growth of focussed organizations, Project Management Institute (PMI) and International Project Management Association (IPMA). These associations are eligible as organizers of a no. of conferences and also act as promoters of the standardization of PM and certification for project managers. They also include professionals by a growing number of members who need techniques, certification and standards tactics for professional growth (Söderlund, 2004).

Therefore, organization behaviour may impact on the success of projects. Organization behaviour may improve project process via empowerment (certification programs) of project manager and project team in order to identify and facilitate behavioural factors. With these critical success factors, there is an ease of attaining desired outcomes (performance and profitability).

\section{Problem statement}

Lindkvist et al. (1998) stated that conventional PM functions focus very much on an analytical course of project. This is powerless to clarify systemic atmosphere presents in most projects. According to Söderlund (2002) "How do project organizations behave? Several authors have stressed that we only have limited knowledge of the behaviour of project organizations". The major argument here is, several methods and models presented in the PM field do not increase or elucidate significantly on the behaviour of project businesses. One valuable image of projects is associated with "temporary firms"(Goodman \& Goodman, 1976; Lundin \& Söderholm, 1995).

Bendoly and Swink (2007) concentrated on describing the effects of information on decision makers' actions and perceptions in an environment where different projects were executed concurrently. They performed a controlled experiment to simulate different perspectives which are common to a multi-party project management environment. They reported that bigger visibility of situational information in this environment could influence on project outcomes primarily by influencing a project manager's actions to his/her task. Environment (situational information) effects act primarily by upsetting actions and perceptions of a project manager associated with both urgency assigned to his/her task and behaviour of others (Bendoly \& Swink, 2007). Regrettably, such wide thought of function of information mean is not yet common practice among top rank managers. Usually, their opinions of point with planning and scheduling skills of IT PM approach may lead them to neglect behavioural implications of their habit (Gray \& Larson, 2000; Tukel \& Rom, 1998). According to Bendoly and Swink (2007) "yet there has been very little study of the behavioural factors that affect decision makers' willingness to share resources. Moreover, researchers have not addressed the impacts of sharing behaviours on local, global, and future project outcomes". PM seems to be a research topic with gauges of bringing diverse areas to unify on a principal spectacle of research, i.e. projects. The level of insight is challenging and interesting but should be accompanied by a continuing debate of some primary issues about PM study. There is essential of an ornate discussion on identity and content of subject of PM learning. Morris (1994) for example stated that academic growing of discipline in project-based actions is not fast. Packendorff (1995) appealed that PM largely depends on a usual theory that is insufficiently empirical (Meyerson, Weick, \& Kramer, 1996; Söderlund, 2000).

This paper tries to recognise and present critical success factors (CSFs) for behaviour related to fundamental theoretical issues associated with PM research. The primary objective is make sure about the progress of PM research on a general level and a certification programme for project manager. The study claims that there is a necessity to be chatted - question that should be at the essential for the aim of development for PM success and project success (PS). 


\section{Literature review}

An endeavour activity, as defined by the view of $\mathrm{k}$ Wysocki (2000), "is an arrangement of homogeneous, heterogeneous, and interlinked activities having uniform goal or purpose that must be accomplished by a definite time, within constrains of resources, and according to description". As stated by the PMI's institute (2008) and according to Project Management Body of Knowledge (PMBoK) project, project management includes temporary endeavours conducted to accomplish desired aims and goals within limit a unique scope, budget and time frame. Project runs thoroughly via a proper cycle of life. The cycle of project life is a sensible planning of actions to reach the goals of a project. The project life cycle (PLC) has been the source for catching and informative intrinsic fluctuations of project organizations, for instant, in sense of planning and close out stages. However, this is only one sideway and decision phase. This is a path of watching at the behaviour of project firms. Experts like Gersick (1988) and Gersick (1989) have credibly shown that PLC is not a unique clarification of how really projects progress. In this view, Kreiner (1992) stated that, literature on project businesses has emphasized themes as "participation", "learning", "commitment" and "action" for aim of focus on the behavioural aspects of such organizations. According to Rockart (1978), Critical success factor (CSF) is a management term for an element that is essential for a firm or project to reach its mission. Chua et al. (1999) and Lam et al. (2008) explained CSFs in terms of management of cost, time and quality. By the view of Caralli et al. (2004), the critical success factor way is a method for diagnosing chief success elements. Project success factors have become a famous theme in research (Belassi \& Tukel, 1996; Pinto \& Slevin, 1988; Tishler et al., 1996; White \& Fortune, 2002). The Project Implementation Profile (PIP) model facilitates the project manager to measure the success of a specific project through 10 identified CSFs (Pinto \& Slevin, 2006). Pinto and Slevin (1987) introduced valuable contribution of PIP to project management discipline by verifying different methods to utilize CSFs to detect a project's position. They introduced PIP tool as CSFs including client consultation, personnel, top management support, project schedule/plans, project mission, client acceptance, technical tasks, communication, monitoring and feedback, and troubleshooting (Andersen et al., 2006). Top management's support (TMS) and Top management support are some common factors continuously cited as the record relevant success factor in the projects of IS implementation (Hong \& Kim, 2002; Ramayah et al., 2007; Yusuf et al., 2006; Arumugam et al., 2011; Digalwar \& Sangwan, 2007; Umble et al., 2003). The Management support includes facility in finance, moral, ethics and resource distribution to attain the project/business purposes on time and the for the success of enterprise resource planning (ERP) implementation, involvement of top management is critical (Bhatti, 2005; Kumar et al., 2000; Rasmy et al., 2005).

Like other factors for implementation of project, acceptance is a more critical stage compared with any other factor. According to Locus (2009) "an implementation strategist, discusses the importance of user participation in the early stages of a system development as a way of improving the likelihood of later acceptance". According to Wilson (2009), project management is the utilization of mediators to function as liaison between the design plan, or team for implementation. User acceptance of an organization was a vital regarded substitute degree of Information System (IS) success in the earlier research. During discussion at this stage, two issues must be clarified. First, some authors distinguish between project management success (for measurement to cover the widespread along with traditional measurement of performance in order to cover ("cost, time and quality") and project success (measured against the overall objectives of the project). The second distinction is significant too; which shows the difference between success criteria; i.e. it is helpful via measurement to judge the business or failure or success of project and success factors; those inputs that affect the system of management are able to lead directly or indirectly toward business or the project success (Cooke-Davies, 2002). Meanwhile, empirical works indicating the connection between CSFs (organizational factors) and their influence on project success are still insufficient (AL-Dubai \& Alaghbari, 2018; Al-Sabahi et al., 2014; Turner \& Müller, 2005). LeeKelley and Kin Leong (2003) investigated which project management Knowledge Areas were assumed critical to project success and whether influences on leadership styles associated with the project manager's for perception of control. Yang et al. (2011) performed a survey on six schools of leadership and 
reported two types of leadership; namely transactional and transformational leadership. In Pakistan, Planning Commission of Pakistan is government entity and liable for growth of projects. Planning Commission of Pakistan functions in every area of the Pakistan. This body facilitates guidelines concerning to standards of quality, monitoring system and planning \& control of the projects (Mobey \& Parker, 2002). Pakistan is a developing country and is able to make herself at better position by taking on of human resources best practiced by the best utilization of HR resources availability. Among this, there are 49.19 $\%$ of female population according to World Bank (Khanum, 2013). Since advancement entails a large number of projects and HRM is assumed as fundamental exercise of the project-based businesses (Huemann et al., 2007), it is essential to estimate the impacts of practices of HR following "Universalistic Perspective" on project success of project-based organizations in Pakistan. Among Muslim countries, Pakistan is the second largest Muslim country in terms of the population (Rai et al., 2007).

\section{Methodology}

Traditionally, projects used to be accomplished via technical arrangements in place of behavioural arrangements (Belout \& Gauvreau, 2004). PIP tool pointed out behavioural factors like client acceptance and top management support (Pinto \& Prescott, 2006). PIP has two types of factors including hard and soft. Hard factors cover operational and technical aspects of project and soft covers behavioural variables. Both are equally crucial to project success. All these 10 factors are known as PIP as well as independent variables which is both a framework for the project implementation process as well as a diagnostic instrument for a project manager (Rosacker \& Olson, 2008). This is quantitative, deductive and explorative study. Here are hypotheses for study.

H1. There is a significate relationship between behavioural factors and project success.

H1a. Transactional leadership style maintains a moderating effect on the relationship between behavioural factors and project success.

H1b. Transformational leadership style maintains a moderating effect on the relationship between behavioural factors and project success.

This study has two CSFs related to behaviour aspects including client acceptance and top management support to measure project success. This is quantitative and explorative study in IT projects in Pakistan. The research target population covers 1720 IT companies in Pakistan available on directory of www.pseb.org.pk. According to Krejcie and Morgan (1970), sample size was 313, simple random sampling was chosen and unit of analysis was individual. Closed-ended questionnaire was adopted for selected constructs from PIP. Each independent variable had five items and dependent variable had thirteen items. Data collection means were paper-pencil and google form. 658 questionnaires were distributed and usable retained was 223 (33. 89\%). Likert scale of 5 and confident level of $95 \%$ for two tail analysis were used. Moderating effect were checked by categorical moderators of Transactional and Transformational Leadership Styles. Results confirm that relationship between independent variables and project success vary according to each subgroup of moderator or different influence patterns would be found for each re-sample derived from full sample according to each subgroup of moderators. The reason for this is that the coefficient appear is to be appropriate because of the fact that study subdivided/re-sampling/sub-group of full sample.

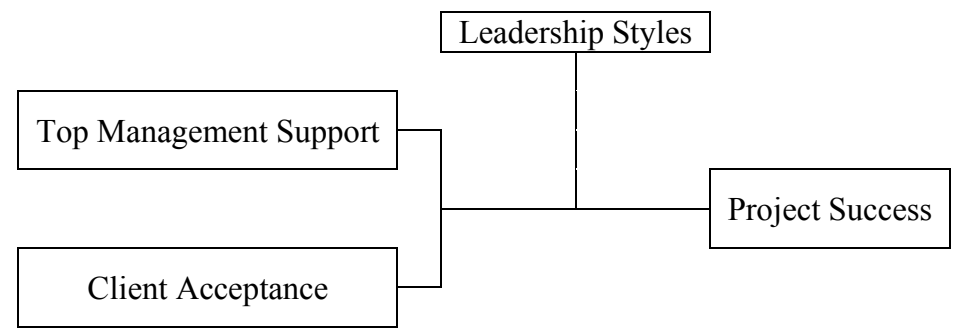

Fig. 1. Research Model 
This study tests hypotheses H1a and H1b for each moderator's sub-group with related control accordingly similar studies (e.g. Belout \& Gauvreau, 2004; Keil et al., 2000; Pinto \& Prescott, 1988; Shen et al., 2011). Data analysis is performed with PLS-SEM for structure and measurement model which is shown in Fig. 1.

\section{Analysis and results}

For data analysis this study implements the SmartPLS 3 which is more reliable and validate and the measurement model was examined. Fig. 2 displays full sample based measurement model assessment. Fig. 3 and Fig. 4 display the measurement model assessment for categorical moderation of Transactional Leadership Style and Transformational Leadership Style respectively by re-sampling and by categorical moderation analysis (Belout \& Gauvreau, 2004; Keil et al., 2000; Pinto \& Prescott, 1988; Shen et al., 2011). Moreover, Table 2 shows the results of measurement model assessment. To assess the measurement model, factor loading, Cronbach alpha, composite reliability and average variance extracted (AVE) were examined. According to Hair Jr et al (2016), "all the items having factor loading less than 0.5 were deleted. In this study threshold level for Cronbach alpha was 0.7 , composite reliability 0.7 and average variance extracted (AVE) 0.5 was examined". The outcomes in Table 1 present that all the constructs achieved the minimum threshold level. Moreover, discriminant validity is also presented in Table 1 which achieved the external consistency. Table 1 has the values of full sample with re-sampling of data by transactional and transformational leadership styles. In Table 2, findings revealed that there was a positive and significate relationship between behavioural factors and project success (H1). Moreover, there was a positive and significate relationship between behavioural factors and project success under control transactional leadership style (H1a) similar to (H1b) for transformational leadership style.

Table 1

The Convergence, Reliability Analysis, Cronbach Alpha and Discriminant Validity

\begin{tabular}{|c|c|c|c|c|c|c|}
\hline & CR & AVE & Cronbach Alpha & TMS & $\mathbf{C A}$ & PS \\
\hline \multicolumn{7}{|c|}{ Full Sample $(\mathrm{N}=223)$} \\
\hline TMS & 0.904 & 0.654 & 0.867 & 0.877 & & \\
\hline $\mathrm{CA}$ & 0.930 & 0.508 & 0.919 & 0.710 & 0.809 & \\
\hline PS & 0.930 & 0.770 & 0.901 & 0.409 & 0.577 & 0.713 \\
\hline \multicolumn{7}{|c|}{ Transactional Leadership Style $(\mathrm{N}=112)$} \\
\hline TMS & 0.939 & 0.792 & 0.915 & 0.890 & & \\
\hline $\mathrm{CA}$ & 0.925 & 0.711 & 0.898 & 0.751 & 0.843 & \\
\hline PS & 0.919 & 0.512 & 0.904 & 0.453 & 0.603 & 0.715 \\
\hline \multicolumn{7}{|c|}{ Transformational Leadership Style $(\mathrm{N}=111)$} \\
\hline TMS & 0.922 & 0.748 & 0.888 & 0.865 & & \\
\hline $\mathrm{CA}$ & 0.938 & 0.579 & 0.927 & 0.662 & 0.765 & \\
\hline PS & 0.876 & 0.586 & 0.824 & 0.386 & 0.583 & 0.761 \\
\hline
\end{tabular}

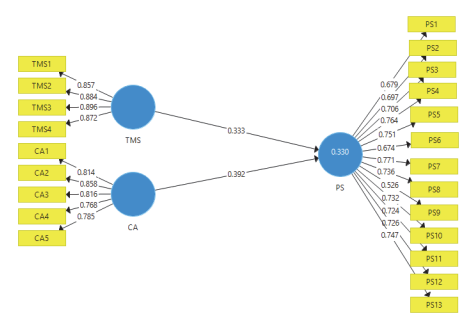

Fig. 2. Full Model ( $\mathrm{N}=223)$

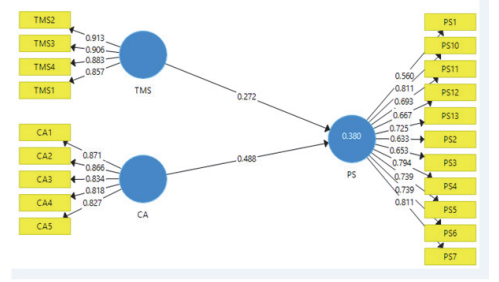

Fig. 3. Transactional Leadership Style $(\mathrm{N}=112)$

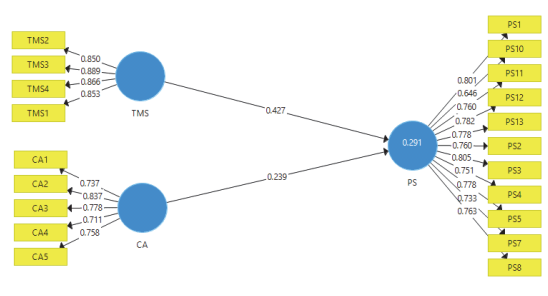

Fig. 4. Transformational Leadership Style $(\mathrm{N}=111)$

Table 2 presents total variance explained through $\mathrm{R}^{2}$ which seems to be substantial for full sample and for each sub-dimension (Cohen, 1988). According to Cohen (1988), "r-square value 12 or below indicate low, between .13 to .25 values indicate medium, .26 or above and above values indicate high effect size". In this respect, our models represent low and medium effect sizes. Table 3 presents the effect size. 
According to Cohen (1988), " $\mathrm{f}^{2}$ values of $0.02,0.15$, and 0.35 for the significant independent variables represent weak, moderate and substantial effects, respectively".

Table 2

Results of structural model analysis for full sample and re-sampling

\begin{tabular}{|c|c|c|c|c|c|c|}
\hline Hypothesis & Relationship/Effect & Path Coefficient ( $\beta$ ) & T Statistics & P Values & Coefficient of determination (R2) & Decision \\
\hline \multicolumn{7}{|c|}{ Full Sample $(\mathrm{N}=223)$} \\
\hline \multirow[t]{2}{*}{$\mathrm{H} 1$} & $\mathrm{TMS} \rightarrow \mathrm{PS}$ & 0.333 & $5.525 * * *$ & 0.000 & \multirow{2}{*}{0.330} & \multirow{2}{*}{$\begin{array}{l}\text { Supported } \\
\text { Supported }\end{array}$} \\
\hline & $\mathrm{CA} \rightarrow \mathrm{PS}$ & 0.392 & $6.934 * * *$ & 0.000 & & \\
\hline \multicolumn{7}{|c|}{ Transactional Leadership Style $(\mathrm{N}=112)$} \\
\hline \multirow[t]{2}{*}{ H1a } & $\mathrm{TMS} \rightarrow \mathrm{PS}$ & 0.272 & $3.205 * *$ & 0.001 & \multirow{2}{*}{0.380} & \multirow{2}{*}{$\begin{array}{l}\text { Supported } \\
\text { Supported }\end{array}$} \\
\hline & $\mathrm{CA} \rightarrow \mathrm{PS}$ & 0.488 & $6.608 * * *$ & 0.000 & & \\
\hline \multicolumn{7}{|c|}{ Transformational Leadership Style $(\mathrm{N}=111)$} \\
\hline \multirow[t]{2}{*}{$\mathrm{H} 1 \mathrm{~b}$} & $\mathrm{TMS} \rightarrow \mathrm{PS}$ & 0.427 & $5.155^{* * *}$ & 0.000 & \multirow{2}{*}{0.291} & \multirow{2}{*}{$\begin{array}{l}\text { Supported } \\
\text { Supported }\end{array}$} \\
\hline & $\mathrm{CA} \rightarrow \mathrm{PS}$ & 0.239 & $2.698 * *$ & 0.007 & & \\
\hline
\end{tabular}

Note. Two-tailed test. Significant at $\mathrm{p}<0.05^{*}, \mathrm{p}<0.01^{* *}$ and $\mathrm{p}<0.001^{* * *}$.

Furthermore, Table 4 presents quality of model via predictive relevance $\left(\mathrm{Q}^{2}\right)$ and effect size $\mathrm{F}^{2}$. In the current study $\mathrm{Q}^{2}$ is more than zero as recommended by Henseler et al. (2009). Thus, the model achieved the certain quality as the Q2 is more than zero. All above assumptions were for full sample, transactional leadership style (moderator) and transformational leadership style (moderator) in Table 3 and Table 4.

Table 3

Effect size of the relationship between CSFs and project success

\begin{tabular}{lllll}
\hline Relationship & $\mathbf{R}^{\mathbf{2}}$ Included & $\mathbf{R}^{\mathbf{2}}$ Excluded & Effect Size $\left(\mathbf{F}^{2}\right)$ & Rating \\
\hline Full Sample (N=223) & & & & \\
TMS $\rightarrow$ PS & 0.330 & 0.233 & 0.145 & Medium \\
CA $\rightarrow$ PS & 0.330 & 0.193 & 0.204 & Large \\
\multicolumn{2}{l}{ Transactional Leadership Style (N=112) } & & & \\
TMS $\rightarrow$ PS & 0.380 & 0.316 & 0.103 & Medium \\
CA $\rightarrow$ PS & 0.380 & 0.169 & 0.340 & Large \\
\multicolumn{2}{l}{ Transformational Leadership Style (N=111) } & & & \\
TMS $\rightarrow$ PS & 0.291 & 0.124 & 0.236 & Large \\
CA $\rightarrow$ PS & 0.291 & 0.241 & 0.071 & Medium \\
\hline
\end{tabular}

Table 4

Construct Crossvalidated redundancy value

\begin{tabular}{|c|c|c|c|}
\hline & SSO & SSE & $Q^{2}$ (=1-SSE/SSO) \\
\hline \multicolumn{4}{|c|}{ Full Sample $(\mathrm{N}=223)$} \\
\hline PS & $2,899.000$ & $2,462.680$ & 0.151 \\
\hline \multicolumn{4}{|c|}{ Transactional Leadership Style (N=112) } \\
\hline PS & $1,232.000$ & $1,021.934$ & 0.171 \\
\hline \multicolumn{4}{|c|}{ Transformational Leadership Style $(\mathrm{N}=111)$} \\
\hline PS & $1,221.000$ & $1,034.692$ & 0.153 \\
\hline
\end{tabular}

All above value fulfil the assumptions.

\section{Conclusion}

Results have revealed that behavioural factors had positive and significant relationship with project success. This is confirmed by Rosacker and Olson (2008) as "The information as well as insights on Top Management Support has positive impact presented by this study can be of assistance in attaining successful project". Moreover, the success of project could be perceived by project manager. 
Transactional Leadership Style, has concerned for process, preferred on simple or engineering projects. This style is suited for repositioning projects which have more need to avail the targets. Like renewal projects, repositioning projects require motivation, communication, and self-awareness especially in IT sector. Vision of project manager plays vital role for the success of the projects. Under control of Transactional Leadership Style, behavioural factors such as Top Management Support (TMS) and Client Acceptance (CA) have positive influence on IT project success in Pakistan. Transformational Leadership Style has concern for relationship for renewal projects and suited for medium to complex projects. This style motivates subordinates for improving their performance to avail desired expectations. Transformational Leadership Style enhances creativity and innovation in team by exchanging and sharing of information among members. Renewal projects have impacts on stakeholders. With the support of the above arguments, behavioural factors of current study have positive impact for IT project success with moderation of Transformational Leadership Style. Practitioners must follow recommendation to handle project with behaviour manner. Future research will be done by introducing moderator of accountability.

\section{Acknowledgement}

The authors would like to thank the anonymous referees for constructive comments on earlier version of this paper.

\section{References}

AL-Dubai, M. M., \& Alaghbari, M. A. (2018). Relationship between organization factors towards project success. Journal of Internet Banking and Commerce, 23(2).

Al-Sabahi, M. H., Al-Hamidi, A. A., Ramly, A., \& Rejab, K. M. (2014). Exploring criteria and critical factors for governmental projects implementation in Yemen: a case study. Journal of Surveying, Construction and Property, 5(2), 1-17.

Andersen, E. S., Birchall, D., Arne Jessen, S., \& Money, A. H. (2006). Exploring project success. Baltic journal of management, 1(2), 127-147.

Arumugam, V., Mojtahedzadeh, R., \& Malarvizhi, C. (2011). Critical success factors of total quality management and their impact on performance of Iranian Automotive Industry. Paper presented at the International Conference on Innovation, Management and Service IPEDR.

Belassi, W., \& Tukel, O. I. (1996). A new framework for determining critical success/failure factors in projects. International journal of project management, 14(3), 141-151.

Belout, A., \& Gauvreau, C. (2004). Factors influencing project success: the impact of human resource management. International journal of project management, 22(1), 1-11.

Bendoly, E., \& Swink, M. (2007). Moderating effects of information access on project management behavior, performance and perceptions. Journal of Operations Management, 25(3), 604-622.

Bhatti, R. (2005). Critical success factors for the implementation of ERP: Empirical validation. Paper presented at the The second International Conference on Innovation in Information Technology (ITT'05) in Dubai, UAE (Sept 26-28, 2005).

Caralli, R. A., Stevens, J. F., Willke, B. J., \& Wilson, W. R. (2004). The critical success factor method: establishing a foundation for enterprise security management. Retrieved from

Chua, D. K. H., Kog, Y.-C., \& Loh, P. K. (1999). Critical success factors for different project objectives. Journal of construction engineering and management, 125(3), 142-150.

Cohen, J. (1988). Statistical power analysis for the behavioral sciences. Hillsdale, NJ: Lawrence Erlbaum.

Cooke-Davies, T. (2002). The "real" success factors on projects. International Journal of Project Management, 20(3), 185-190.

Digalwar, A. K., \& Sangwan, K. S. (2007). Development and validation of performance measures for world class manufacturing practices in India. Journal of Advanced Manufacturing Systems, 6(01), 2138.

Galbraith, J. R. (1977). Organization design: Addison Wesley Publishing Company. 
Gällstedt, M. (2003). Working conditions in projects: perceptions of stress and motivation among project team members and project managers. International Journal of Project Management, 21(6), 449-455.

Gersick, C. J. (1988). Time and transition in work teams: Toward a new model of group development. Academy of management journal, 31(1), 9-41.

Gersick, C. J. (1989). Marking time: Predictable transitions in task groups. Academy of Management Journal, 32(2), 274-309.

Goodman, R. A., \& Goodman, L. P. (1976). Some management issues in temporary systems: A study of professional development and manpower-the theater case. Administrative Science Quarterly, 494-501.

Gray, C. L., \& Larson, E. W. (2000). Project Management: The Managerial Process. Irwin/McGrawHill.

Hair Jr, J. F., Hult, G. T. M., Ringle, C., \& Sarstedt, M. (2016). A primer on partial least squares structural equation modeling (PLS-SEM): Sage Publications.

Henseler, J., Ringle, C. M., \& Sinkovics, R. R. (2009). The use of partial least squares path modeling in international marketing. In New challenges to international marketing (pp. 277-319): Emerald Group Publishing Limited.

Hong, K.-K., \& Kim, Y.-G. (2002). The critical success factors for ERP implementation: an organizational fit perspective. Information \& Management, 40(1), 25-40.

Huemann, M., Keegan, A., \& Turner, J. R. (2007). Human resource management in the project-oriented company: A review. International journal of project management, 25(3), 315-323.

Institute, P. m. (2008). A guide to the project management body of knowledge.

Keil, M., Tan, B. C., Wei, K.-K., Saarinen, T., Tuunainen, V., \& Wassenaar, A. (2000). A cross-cultural study on escalation of commitment behavior in software projects. MIS quarterly, 299-325.

Khanum, A. (2013). An Overview of Pakistani Women in Education, Science and Research.

Kreiner, K. (1992). The Postmodem Epoch of Organization Theory. International Studies of Management \& Organization, 22(2), 37-52.

Krejcie, R. V., \& Morgan, D. W. (1970). Determining sample size for research activities. Educational and psychological measurement, 30(3), 607-610.

Kumar, K., Van Hillegersberg, J., \& Experiences, E. (2000). Evolution. Communications of the ACM, 43(4), 23-26.

Lam, E. W., Chan, A. P., \& Chan, D. W. (2008). Determinants of successful design-build projects. Journal of construction engineering and management, 134(5), 333-341.

Lee-Kelley, L., \& Kin Leong, L. (2003). Turner's five-functions of project-based management and situational leadership in IT services projects. International journal of project management, 21(8), 583591.

Lindkvist, L., Soderlund, J., \& Tell, F. (1998). Managing product development projects: on the significance of fountains and deadlines. Organization studies, 19(6), 931-951.

Locus, D. (2009). Project Management Handbook. New York; Van Nostrand Reinhold Co.

Lundin, R. A., \& Söderholm, A. (1995). A theory of the temporary organization. Scandinavian Journal of management, 11(4), 437-455.

Meyerson, D., Weick, K. E., \& Kramer, R. M. (1996). Swift trust and temporary groups. Trust in organizations: Frontiers of theory and research, 166, 195.

Mobey, A., \& Parker, D. (2002). Risk evaluation and its importance to project implementation. Work Study, 51(4), 202-208.

Morris, P. W. (1994). The management of projects: Thomas Telford.

O'Reilly, C. A., \& Chatman, J. (1986). Organizational commitment and psychological attachment: The effects of compliance, identification, and internalization on prosocial behavior. Journal of applied psychology, 71(3), 492.

Packendorff, J. (1995). Inquiring into the temporary organization: new directions for project management research. Scandinavian Journal of management, 11(4), 319-333.

Pinto, J. K., \& Prescott, J. E. (1988). Variations in critical success factors over the stages in the project life cycle. Journal of management, 14(1), 5-18. 
Pinto, J. K., \& Prescott, J. E. (2006). Changes In Critical Success Factor Importance Over the Life of a Project.

Pinto, J. K., \& Slevin, D. P. (1987). Critical factors in successful project implementation. IEEE transactions on engineering management(1), 22-27.

Pinto, J. K., \& Slevin, D. P. (1988). Project success: definitions and measurement techniques.

Pinto, J. K., \& Slevin, D. P. (2006). Critical factors in successful project implementation.IEEE transactions on engineering management (1), 22-27.

Puffer, S. M. (1987). Prosocial behavior, noncompliant behavior, and work performance among commission salespeople. Journal of applied psychology, 72(4), 615.

Rai, S., Shah, N., \& Avaz, A. (2007). Achieving gender equality in public offices in Pakistan.

Ramayah, T., Roy, M. H., Li, K. B., Jantan, M., Zbib, I., \& Ahmed, Z. (2007). Type of procurement and operational performance: comparing e-procurement and offline purchasing. International Journal of Services and Operations Management, 3(3), 279-296.

Rasmy, M., Tharwat, A., \& Ashraf, S. (2005). Enterprise resource planning (ERP) implementation in the Egyptian organizational context. Paper presented at the Proceedings of the EMCIS International Conference.

Rockart, J. F. (1978). Chief executives define their own data needs. Harvard business review, 57(2), 8193.

Rosacker, K. M., \& Olson, D. L. (2008). Public sector information system critical success factors. Transforming Government: People, Process and Policy, 2(1), 60-70.

Shen, A. X., Cheung, C. M., Lee, M. K., \& Chen, H. (2011). How social influence affects we-intention to use instant messaging: The moderating effect of usage experience. Information Systems Frontiers, $13(2), 157-169$.

Söderlund, J. (2000). Temporary organizing-characteristics and control forms. In Projects as business constituents and guiding motives (pp. 61-74): Springer.

Söderlund, J. (2002). On the development of project management research: schools of thought and critique. International journal of project management, 6(1), 20-31.

Söderlund, J. (2004). Building theories of project management: past research, questions for the future. International journal of project management, 22(3), 183-191.

Tatikonda, M. V., \& Rosenthal, S. R. (2000). Successful execution of product development projects: Balancing firmness and flexibility in the innovation process. Journal of Operations Management, 18(4), 401-425.

Tishler, A., Dvir, D., Shenhar, A., \& Lipovetsky, S. (1996). Identifying critical success factors in defense development projects: A multivariate analysis. Technological forecasting and social change, 51(2), 151-171.

Tukel, O. I., \& Rom, W. O. (1998). Analysis of the characteristics of projects in diverse industries. Journal of Operations Management, 16(1), 43-61.

Turner, J. R., \& Müller, R. (2005). The project manager's leadership style as a success factor on projects: A literature review.

Umble, E. J., Haft, R. R., \& Umble, M. M. (2003). Enterprise resource planning: Implementation procedures and critical success factors. European journal of operational research, 146(2), 241-257.

Verma, D., \& Sinha, K. K. (2002). Toward a theory of project interdependencies in high tech R\&D environments. Journal of Operations Management, 20(5), 451-468.

White, D., \& Fortune, J. (2002). Current practice in project management-An empirical study. International journal of project management, 20(1), 1-11.

Wilson, K. L. (2009). Protect Management Handbook. New York: Van Nostrand Reinhold Co.

Wysocki, R. (2000). Robe Beck Jr, David B Crane. Effective Project Management.

Yang, L.-R., Huang, C.-F., \& Wu, K.-S. (2011). The association among project manager's leadership style, teamwork and project success. International journal of project management, 29(3), 258-267.

Yusuf, Y., Gunasekaran, A., \& Wu, C. (2006). Implementation of enterprise resource planning in China. Technovation, 26(12), 1324-1336. 
(C) 2019 by the authors; licensee Growing Science, Canada. This is an open access article distributed under the terms and conditions of the Creative Commons Attribution (CCBY) license (http://creativecommons.org/licenses/by/4.0/). 